\title{
Concentration of nutrient solution in the hydroponic production of potato minitubers
}

\author{
Concentração da solução nutritiva na produção hidropônica de minitubérculos de batata
}

\author{
Manuel Benito Novella ${ }^{\mathrm{I}}$ Jerônimo Luiz Andriolo $^{\mathrm{I}^{*}}$ Dilson Antônio Bisognin ${ }^{\mathrm{I}}$ \\ Clarissa Melo Cogo ${ }^{\mathrm{I}}$ Maurício Guerra Bandinelli ${ }^{\mathrm{I}}$
}

\begin{abstract}
The effect of the nutrient solution concentration on potato plant growth and minituber yield were determined in a sand closed hydroponic system. Minitubers and micropropagated plantlets of the cv. 'Macaca' were used. Treatments were five nutrient solution concentrations at electrical conductivities (EC) of 1.0 (T1), 2.2 (T2), 3.4 (T3), 4.7 (T4) and $5.8 d S \mathrm{~m}^{-1}$ (T5). The split plot randomised experimental design was used with three replications. Plants from minitubers produced higher fresh and mean weight of minitubers, shoot dry mass and leaf area index than the micropropagated ones. However, higher dry mass of minitubers was found with micropropagated plantlets compared to minitubers. The concentration of the nutrient solution did not affect minituber number. Increasing the nutrient solution concentration decreased total and minituber dry mass production of micropropagated plantlets and plant growth and minituber production of minituber-originated plants. Low concentration of nutrient solution at an EC of about $1.0 \mathrm{dS} \mathrm{m^{-1 }}$ can be used in the hydroponic production of potato minitubers of both micropropagated and minituber-originated plants.
\end{abstract}

Key words: Solanum tuberosum, plantlets, plant propagation, electrical conductivity.

\section{RESUMO}

Neste trabalho foi determinado o efeito da concentração da solução nutritiva no crescimento e na produtividade de minitubérculos de batata em um sistema hidropônico fechado empregando areia como substrato. Plântulas micropropagadas e minitubérculos foram plantados em 24 de março de 2004. Os tratamentos foram cinco soluções nutritivas com condutividades elétricas (CE) de 1,0 (T1), 2,2 (T2), 3,4 (T3), 4,7 (T4) e 5,8dS $\mathrm{m}^{-1}$ (T5). O experimento foi conduzido em parcelas subdivididas no delineamento inteiramente casualizado com três repetições. Plantas originadas de minitubérculos produziram mais massa fresca total e média de minitubérculos, massa seca da parte aérea e maior índice de área foliar que plantas micropropagadas. Entretanto, maior massa seca dos minitubérculos foi obtida em plantas micropropagadas. A concentração da solução nutritiva não afetou o número de minitubérculos. O aumento da CE reduziu a massa seca total e dos minitubérculos de plantas micropropagadas e decresceu linearmente o crescimento e a produtividade de minitubérculos de plantas oriundas de minitubérculos. Concentrações baixas de solução nutritiva com valores da ordem de $1,0 \mathrm{dS} \mathrm{m}^{-1}$ podem ser empregadas na produção de minitubérculos de batata a partir de plântulas micropropagadas e minitubérculos.

Palavras-chave: Solanum tuberosum, plântulas, propagação de plantas, condutividade elétrica.

\section{INTRODUCTION}

Nowadays, the propagation of potato (Solanum tuberosum L.) selected clones is hydroponically done, mainly in NFT (MEDEIROS et al., 2002) and aeroponics (FARRAN \& MINGOCASTEL, 2006) growing systems. These systems allow high yields, but they are costly and laborious. Adding substrate to the system is a tool to enhance chemical and physical inertia. As a consequence, labour and energy are saved (ROLOT \& SEUTIN, 1999). Information on hydroponic set up, substrate and nutrient solution composition for potato propagation is scarce.

The electrical conductivity (EC) of the nutrient solution currently used in horticultural crops lies in the range within 1.5 and $4.0 \mathrm{dS} \mathrm{m}^{-1}$ (CASTELLANE

IDepartamento de Fitotecnia, Universidade Federal de Santa Maria (UFSM), 97105-900, Santa Maria, RS, Brasil. E-mail: andriolo@smail.ufsm.br.*Autor para correspondência. 
\&ARAUJO, 1995; MARTINEZ \& SILVAFILHO, 2004; URRESTARAZU, 2004). While low EC may reduce growth, high concentrations may lead to physiological disorders, resulting in reduced growth and yield. The electrical conductivity (EC) threshold above which yield is impaired was reported to be as low as $0.7 \mathrm{dS} \mathrm{m}^{-1}$ for beans (PLAUT, 1997), from 2.0 to $2.6 \mathrm{dS} \mathrm{m} \mathrm{m}^{-1}$ for lettuce (ANDRIOLO et al., 2005) and tomato (LI \& STANGHELLINI, 2001; SONNEVELD, 2004). The threshold reported for field grown potatoes was between 1.6 and $1.7 \mathrm{dS} \mathrm{m}{ }^{-1}$ (REIS JR et al., 1999).

In potato minituber production, nutrient solutions of EC values between 2.0 and $2.5 \mathrm{dS} \mathrm{m}^{-1}$ has been used (MEDEIROS et al., 2002; FARRAN \& MINGO-CASTEL, 2006). Lower nutrient solution concentrations might reduce fertilization costs and higher ones restrict leaf area growth and water consumption. The effect of such practices on potato minituber production has not been reported.

The aim of this research was to determine the effect of nutrient solution concentration on plant growth and tuber yield of potato plants originated from minitubers and micropropagated plantlets, in a closed hydroponic system with sand as substrate.

\section{MATERIAL AND METHODS}

The experimental set up was a closed modified ebb-and-flood hydroponic system in a greenhouse of the Departamento de Fitotecnia, Universidade Federal de Santa Maria, RS, Brazil. A fibre cement tile, $3.05 \mathrm{~m}$ long and $1.10 \mathrm{~m}$ wide with gullies of $0.06 \mathrm{~m}$ high and $0.18 \mathrm{~m}$ wide, was used to sustain the growing bed. It was placed on a nutrient solution reservoir with $1 \%$ slope. The tile gullies and the inner surface of the reservoir were covered with a $100 \mu \mathrm{m}$ polyethylene sheet. The gullies were then filled with $0.015-0.020 \mathrm{~m}$ gauge gravel and covered with a $0.0015 \mathrm{~m}$ polyethylene screen to hold the $0.15 \mathrm{~m}$ high growing bed (substrate) formed by sand of $0.001-0.03 \mathrm{~m}$ particles, $1.6 \mathrm{~kg} \mathrm{dm}^{-3}$ bulk density and $0.111 \mathrm{~L} \mathrm{dm}^{-3}$ maximum water retention capacity. A wood frame was used to maintain this growing bed, which was covered with double faced (black and white) polyethylene sheet. A timer-controlled $520 \mathrm{~L} \mathrm{~h}^{-1}$ submersible pump (8W) was used to deliver the nutrient solution from the reservoir to the upper end of the growing bed, from where it flooded and then drained by gravity (ANDRIOLO, 2006).

The cultivar 'Macaca', the most popular potato cultivar grown in Rio Grande do Sul State during the last ten years was used. Micropropagated plantlets and minitubers were planted on March 24 $4^{\text {th }}, 2004$, in $0.10 \times 0.10 \mathrm{~m}$ spaced holes previously made on the polyethylene sheet. Plantlets remained 15 days before planting in a $0.05 \mathrm{~m}$ layer of nutrient solution for acclimatization. Minitubers (diameter between 0.005 and $0.01 \mathrm{~m}$ ), produced in a previous growing season from plantlets, were beforehand stored at $20^{\circ} \mathrm{C}$ until dormancy breaking.

A standard nutrient solution with electrical conductivity (EC) of $1.0 \mathrm{dS} \mathrm{m}^{-1}$ (T1) was prepared with 13.0 of $\mathrm{NO}_{3}^{-} ; 1.5$ of $\mathrm{H}_{2} \mathrm{PO}_{4}^{-;} ; 1.5$ of $\mathrm{SO}_{4}^{--} ; 4.0$ of Ca ${ }^{++}$; 6.5 of $\mathrm{K}^{+}$and $1.5 \mathrm{mmol} \mathrm{L}^{-1}$ of $\mathrm{Mg}^{++}$, and 0.03 of Mo; 0.26 of B; 0.06 of Cu, 0.50 of Mn, 0.22 of $\mathrm{Zn}$ and $4.0 \mathrm{mg} \mathrm{L}^{-1}$ of chelated Fe. Four additional concentrations were then prepared with concentration coefficients of 2.0 (T2), 3.0 (T3), 4.0 (T4) and 5.0 (T5) from T1. Nutrient solution concentrations were corrected every time a deviation of $10 \%$ was recorded, by adding either water or nutrient solution when necessary. The $\mathrm{pH}$ was kept at 6.0 by adding $\mathrm{H}_{3} \mathrm{PO}_{4}$ or $\mathrm{KOH} 1 \mathrm{~N}$ solutions every time a 0.2 unit deviation was recorded, based upon a titration curve. Therefore, there was no disposal of nutrient solution during the experimental period.

All plants were harvested at 49 days after planting, when old leaves began senescence. Total number of plants per plot was recorded. Minitubers bigger than $0.005 \mathrm{~m}$, were harvested, counted and their fresh weight determined. Dry mass of leaves, stems and minitubers were determined after drying samples at $60^{\circ} \mathrm{C}$ until constant weight. Specific leaf area (SLA) was determined on the basis of dry mass of 100 leaf disks $\left(5 \times 10^{-4} \mathrm{~m}^{2}\right)$, sampled on all leaves. Leaf area index (LAI) was further estimated by extrapolating the SLA to the plant leaf dry mass. Shoot and minituber dry mass were added and divided by the number of plants per plot to obtain total plant dry mass.

A completely randomized split plot experimental design was used, with nutrient solution concentrations as main plots and plantlets and minitubers as subplots. A fibre cement tile constituted the subplot, with three replications of 90 hills each. Border rows and end-row hills were not evaluated. Data were submitted to ANOVA. Means differing significantly by the $\mathrm{F}$ test were compared by the Tukey test for minitubers and micropropagated plantlets and by polynomial regression for EC effects, at 5\% probability of error.

\section{RESULTS AND DISCUSSION}

Actual weekly average EC values were 1.0 (T1), 2.2 (T2), 3.4 (T3), 4.7 (T4) and 5.8dS m ${ }^{-1}$ (T5) (Figure 1). In fact, nutrient solution concentration varies with water uptake by plants. The more concentrated is the 


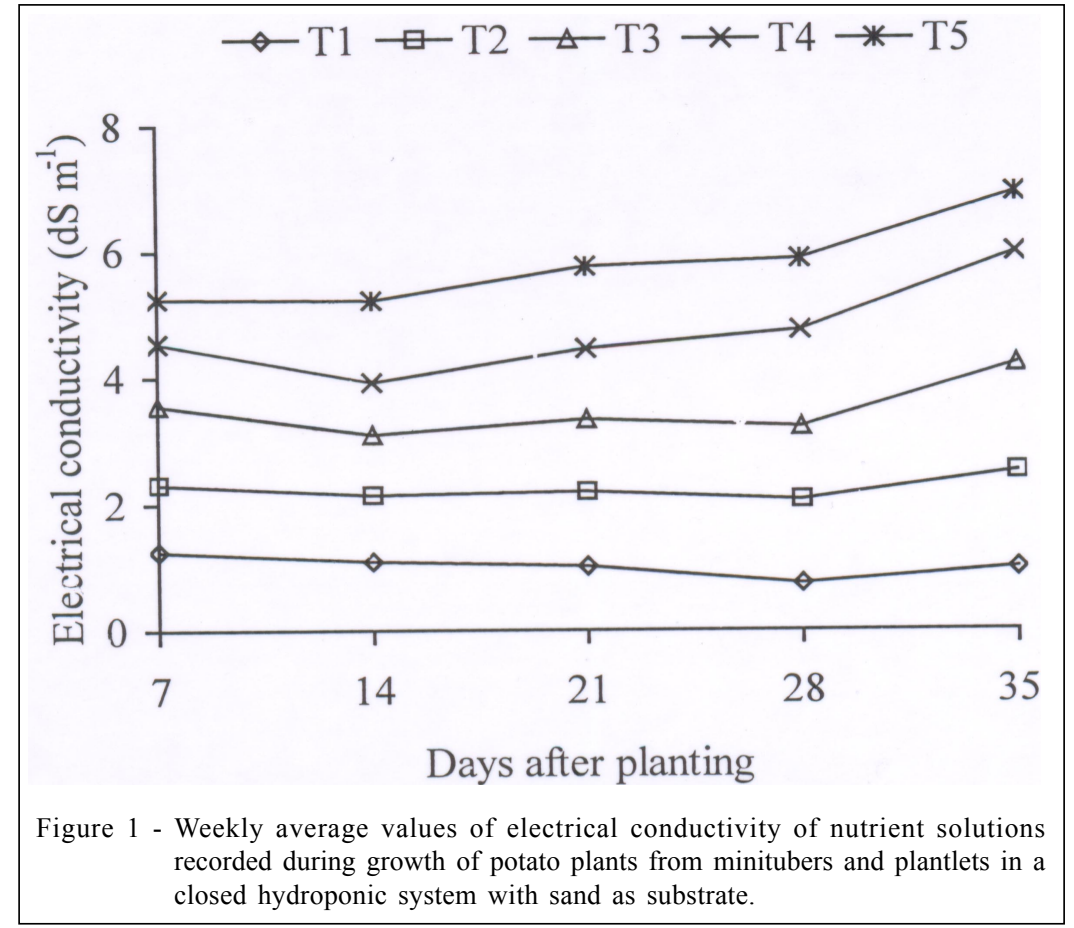

nutrient solution the faster is the increase of EC as a consequence of similar water uptake.

Plants originated from minitubers differed from plantlets (Table 1). Plants from minitubers produced higher fresh and mean weight of minitubers, shoot dry mass and leaf area index than those from plantlets. However, higher dry mass of minitubers was found in plantlets than in minitubers. Total dry mass was similar in plants originated from minitubers and plantlets, with an average of $11.8 \mathrm{~g}$ per plant. Number of minitubers did not differ significantly by effect of neither propagation materials nor nutrient solution concentrations, with an average of 5.9 minitubers per plant (data not shown).

In plantlets, total and minituber dry mass varied with nutrient solution concentrations following a polynomial pattern with respectively maximum values of $13.0 \mathrm{~g}$ per plant at $2.8 \mathrm{dS} \mathrm{m}^{-1}$, and $8.7 \mathrm{~g}$ per plant at
$3.0 \mathrm{dS} \mathrm{m}^{-1}$ (Figure $2 \mathrm{a}$ ). These maximum values were considered as the threshold for nutrient solution concentration, after which plant growth and yield decreases. Increasing one unit of EC decreased tuber fresh and mean weight at a rate of $6.75 \mathrm{~g}$ per plant and $1.17 \mathrm{~g}$ per minituber, respectively (Figure $2 \mathrm{~b}$ ).

In minituber-originated plants, increasing nutrient solution concentration decreased plant growth and minituber production (Figures $3 a$ and $3 b$ ). Therefore, maximum plant growth and minituber yield were found in the EC of $1 \mathrm{dS} \mathrm{m} \mathrm{m}^{-1}$.

In this work, growth and minituber yield of minituber-originated plants were different from plantletoriginated ones. Growth and development of plantlets depend upon carbon fixation by photosynthesis and nutrient uptake by roots, following the balanced exponential model that explains shoot:root growth at vegetative stages (THORNLEY, 1998). In the model,

Table 1 - Fresh weight (TFW), mean weight (TMW) and dry mass of minitubers (TDM), shoot dry mass (SDM) and leaf area index (LAI) of potato plants grown hidroponically from micropropagated plantlets and minitubers. UFSM, Santa Maria, RS, 2004.

\begin{tabular}{|c|c|c|c|c|c|}
\hline & $\mathrm{TFW}\left(\mathrm{g} \mathrm{pl}^{-1}\right)$ & TMW (g) & $\mathrm{TDM}\left(\mathrm{g} \mathrm{pl}^{-1}\right)$ & $\operatorname{SDM}\left(\mathrm{g} \mathrm{pl}^{-1}\right)$ & $\operatorname{LAI}\left(\mathrm{m}^{2} \mathrm{~m}^{-2}\right)$ \\
\hline Plantlets & $40.74 b^{*}$ & $7.56 \mathrm{~b}$ & $7.82 \mathrm{a}$ & $3.68 \mathrm{~b}$ & $10.89 \mathrm{~b}$ \\
\hline Minitubers & $51.26 \mathrm{a}$ & $11.39 \mathrm{a}$ & $6.60 \mathrm{~b}$ & $4.62 \mathrm{a}$ & $12.46 \mathrm{a}$ \\
\hline CV \% & 9.03 & 35.01 & 5.55 & 29.81 & 12.46 \\
\hline
\end{tabular}

*Means followed by different letters in the column differed by the F-test at $5 \%$ probability of error.

Ciência Rural, v.38, n.6, set, 2008. 


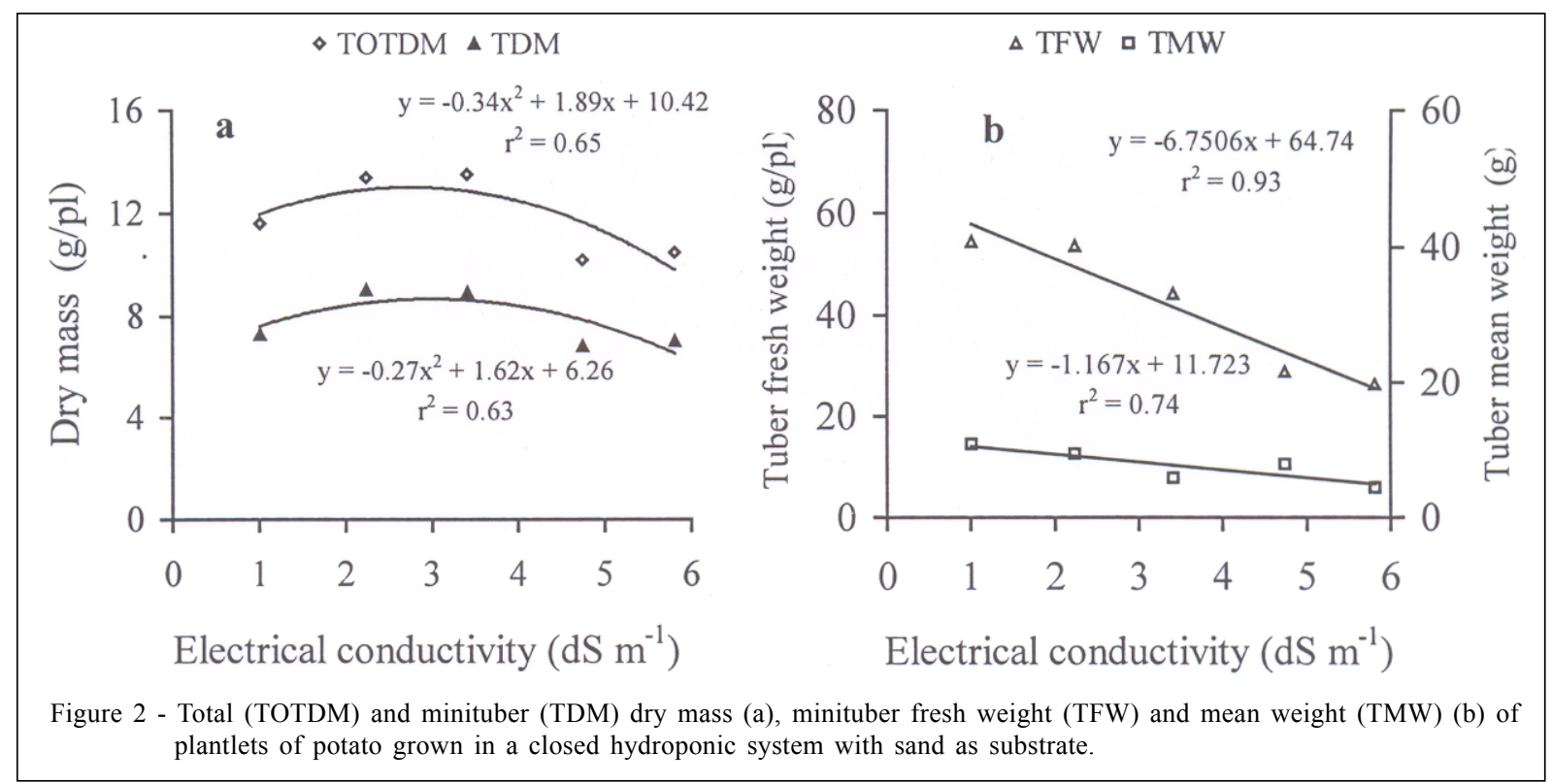

growth rate may be reduced either by lack of carbon or mineral nutrients. However, minituber-originated plants also have reserves of carbon and mineral nutrients to support initial plant growth. The hypothesis of plant growth of plantlets being restricted by low availability of carbon and nutrients at earlier stages of plant development was supported by the polynomial-type growth response (Figure 2a).

The higher values of minituber fresh and mean weight recorded for both propagated materials at the lowest nutrient solution concentration were quite surprising. The main hypothesis to explain this result is the available volume for root growth. In NFT, roots grow in a thin layer of nutrient solution and in bag or pot growing systems roots growth in a small amount of substrate. The volume of root media in our sand growing bed was of about $503 \mathrm{dm}^{3}$, with $55.8 \mathrm{~L}$ of nutrient solution at maximum water retention capacity. This implies that the low concentration of the nutrient solution might be compensated by a greater root surface to absorb water and nutrients. In fact, this hydroponic set up lies in between NFT and soil, in which plants can grow at nutrient solution concentrations lower than those in hydroponic systems.

The average yield of 590 minitubers per $\mathrm{m}^{2}$ that was found in this experiment was similar of those reported in the literature for gravel NFT (ROLOT \&

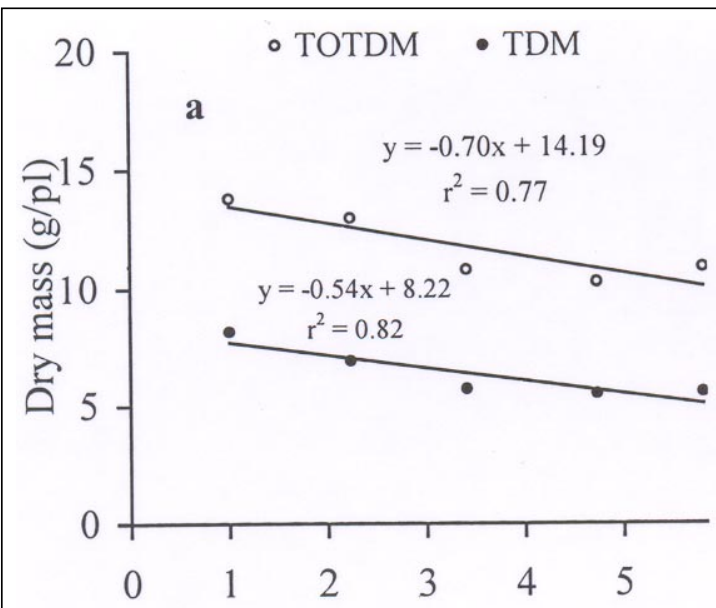

Electrical conductivity $\left(\mathrm{dS} \mathrm{m}^{-1}\right)$

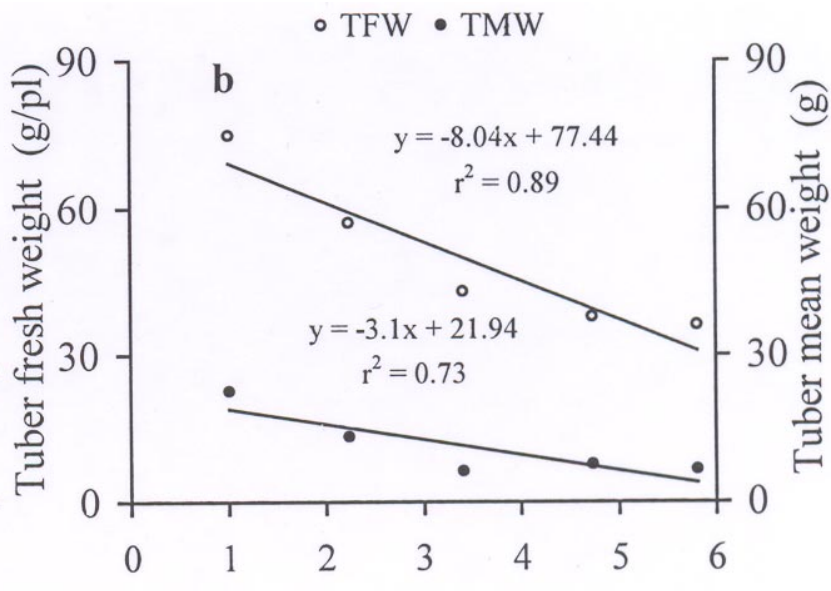

Electrical conductivity $\left(\mathrm{dS} \mathrm{m}^{-1}\right)$

Figure 3 - Total (TOTDM) and minituber (TDM) dry mass (a), minituber fresh weight (TFW) and mean weight (TMW) (b) of minituber plants of potato grown in a closed hydroponic system with sand as substrate.

Ciência Rural, v.38, n.6, set, 2008. 
SEUTIN, 1999; MEDEIROS et al., 2002) and aeroponic systems (FARRAN \& MINGO-CASTEL, 2006). However, the hydroponic production of potato minitubers might be improved by this system. The high volume of nutrient solution maintained by the substrate decreases risks of plant wilt in case of pump failure or electricity shortage. Also, fewer daily fertigations are needed, reducing pump wear and saving energy. The available substrate volume allows the use of low nutrient solution concentrations, diminishing production costs.

\section{CONCLUSIONS}

In a closed hydroponical system with sand as substrate, increasing the nutrient solution concentration until an EC $5.8 \mathrm{dS} \mathrm{m}^{-1}$ does not affect minituber number, but reduces minituber fresh and mean weight. Nutrient solution concentrations of about $1.0 \mathrm{dS} \mathrm{m} \mathrm{m}^{-1}$ may be used to propagate potato seeds from both plantlet and minituber-originated plants.

\section{ACKNOWLEDGEMENTS}

This research receive partial finantial support from FAPERGS - Fundação de Amparo a Pesquisa do Estado do Rio Grande do Sul, grant no 0413284 . We thank CNPq - Conselho Nacional de Desenvolvimento Científico e Tecnológico for the research scholarchips of Jerônimo L. Andriolo and Dilson A. Bisognin.

\section{REFERENCES}

ANDRIOLO, J.L. et al. Growth and yield of lettuce plants under salinity. Horticultura Brasileira, v.23, n.4, p.931934, 2005.

ANDRIOLO, J.L. Sistema hidropônico fechado com subirrigação para produção de minitubérculos de batata. In SIMPÓSIO DE MELHORAMENTO GENÉTICO E PREVISÃO
DE EPIfitias EM BATATA, 2006, Santa Maria. Anais... Santa Maria: UFSM, 2006. p.26-40.

CASTEllane, P.D.; ARAUJO, J.A.C. Cultivo sem solo Hidroponia. 4.ed. Jaboticabal: FUNEP, 1995. 43p.

FARRAN, I.; MINGO-CASTEL, A.M. Potato minituber production using aeroponics: effect of plant density and harvesting intervals. American Journal of Potato Research, v.83, n.1, p.47-53, 2006.

URRESTARAZU, M. La disolución de fertirrigación. In: URRESTARAZU, M. (Ed.). Tratado de cultivo sin suelo. 3.ed. Madrid: Ediciones Mundi-Prensa, 2004. Cap.7, p. 263-303.

LI, Y.L.; STANGHELLINI, C. Analysis of the effect of EC and potencial transpiration on vegetative growth of tomato. Scientia Horticulturae, v.89, p.9-21, 2001.

MARTINEZ, H.E.P.; SILVA FILHO, J.B. Introdução ao cultivo hidropônico de plantas. 2.ed. Viçosa: UFV, 2004. 111p.

MEDEIROS, C.A.B. et al. Produção de sementes pré-básicas de batata em sistemas hidropônicos. Horticultura Brasileira, v.20, n.1, p.110-114, 2002.

PLAUT, Z. Irrigation with low-quality water: effects on productivity, fruit quality and physiological processes of vegetable crops. Acta Horticulturae, n.449, p.591-597, 1997.

REIS JR., R.A. et al. Total soil electrical conductivity and critical soil $\mathrm{K}^{+}$to $\mathrm{Ca}^{2+}$ and $\mathrm{Mg}^{2+}$ ratio for potato crops. Scientia Agrícola, v.56, n.4, p.993-997, 1999.

ROLOT, J.L; SEUTIN, H. Soilless production of potato minitubers using a hydroponic technique. Potato Research, v.42, p.457-469, 1999.

SONNEVELD, C. La nutrición mineral y salinidad en los cultivos sin suelo: su manejo. In: URRESTARAZU (GAVILÁN), M. (Ed.). Tratado de cultivo sin suelo. 3.ed. Madrid: Ediciones Mundi-Prensa, 2004. Cap.8, p.305-367.

THORNLEY, J.H.M. Modelling shoot: root relations: the only way forward? Annals of Botany, v.81, n.1, p.165-171, 1998. 